\title{
The Effects of Social Media Based Brand Communities on Brand Community Markers, Value Creation Practices, Brand Trust and Brand Loyalty
}

Final Version: http://www.sciencedirect.com/science/article/pii/S0747563212001203

\begin{abstract}
Social media based brand communities are communities initiated on the platform of social media. In this article, we explore whether brand communities based on social media (a special type of online brand communities) have positive effects on the main community elements and value creation practices in the communities as well as on brand trust and brand loyalty. A survey based empirical study with 441 respondents was conducted. The results of structural equation modeling show that brand communities established on social media have positive effects on community markers (i.e., shared consciousness, shared rituals and traditions, and obligations to society), which have positive effects on value creation practices (i.e., social networking, community engagement, impressions management, and brand use). Such communities could enhance brand loyalty through brand use and impression management practices. We show that brand trust has a full mediating role in converting value creation practices into brand loyalty. Implications for practice and future research opportunities are discussed.
\end{abstract}

Keywords: Brand community; social media; brand loyalty; value creation practices; community markers; brand trust. 


\section{The Effects of Social Media Based Brand Communities on Brand Community Markers, Value Creation Practices, Brand Trust and Brand Loyalty}

\section{Introduction}

Marketers are very eager to learn about, organize, and facilitate brand communities (e.g., McAlexander, Schouten, \& Koening, 2002; Schau, Muniz, \& Arnould, 2009; Zhou et al., in press), which include a series of connections and relationships among people who admire a brand (Muniz \& O’Guinn, 2001). The reasons behind such interest in brand communities include the advantages of learning customer perceptions of new product offerings and competitive actions; maximizing opportunities to attract and collaborate closely with highly loyal consumers of the brand (Franke \& Shah, 2003; McAlexander et al., 2002); influencing members' evaluations and actions (Muniz \& Schau, 2005); rapidly disseminating information (Brown, Kozinets, \& Sherry, 2003; Jin et al., 2009); and most importantly gaining a "holy grail" of loyal customers (McAlexander et al., 2002). On the other hand, the dramatic popularity and inherent advantages of the vast reach, low cost, high communication efficiency of social media are tempting many companies to participate in such spaces (Kaplan \& Haenlein, 2010).

Taking advantage of the capabilities of both brand community and social media, several companies are using social networking sites to support the creation and development of brand communities (Kaplan \& Haenlein, 2010; Muniz \& O’ Guinn, 2001). Brands such as Jeep with famous offline brand communities (Schau et al., 2009) try to connect with their customers and enhance their brand communities on such social networking sites as MySpace and Facebook. However, despite research on offline brand communities, few studies deal with online brand communities, and especially the new phenomenon of social media based brand communities. Since these brand communities are becoming more important and prevalent, it is necessary for 
both marketers and researchers to have more insights about them.

Muniz and O' Guinn (2001) found evidence of brand communities in both face-to-face and computer-mediated environments. Their ethnographic study identified the presence of the three traditional markers of community (i.e., shared consciousness, shared rituals and traditions, and obligations to society) within brand communities. In their meta-analysis, Schau, Muniz, and Arnould (2009) identified four groups of practices through which value is co-created in brand communities. Building on these studies plus the brand trust and loyalty literatures, we extend the concept of brand community to social media and find evidence of the three community markers in brand communities established on social media websites. Then we show how these communities create value and how they affect brand loyalty through brand trust.

Due to the rapid growth of social media and the motivation of brand owners to participate in social media, our purpose is to explore whether brand communities based on social media (i.e., a special type of online brand communities) have positive effects on the main community elements and on community value creation practices, as well as on brand loyalty. Toward this goal, we first develop a nomological network of relationships between brand community markers, value creation practices, brand trust, and brand loyalty. Then, we test the network and hypotheses quantitatively by estimating a structural equation model using survey data from a sample of social media website users who are members of different brand communities on the social media websites. We develop and validate new scales to measure some community related constructs such as shared consciousness, rituals and traditions, and obligations to society, which may be useful in conducting future survey-based brand community studies.

The remainder of this article is structured as follows. We begin with a brief review of the theoretical background of important concepts such as brand community and social media. Then 
we develop our hypotheses and model, followed by testing the hypotheses and reporting the results. We conclude with a discussion of managerial significance, theoretical and practical implications, and limitations and avenues for future research.

\section{Theoretical Background}

\subsection{Social media}

People spend more than one third of their walking day consuming social media (Lang, 2010). Facebook alone, the hallmark of social media, has over 800 million active users. The unique aspects of social media and its immense popularity have revolutionized marketing practices such as advertising and promotion (Hanna, Rohm, \& Crittenden, 2011). Social media has also influenced consumer behavior from information acquisition to post purchase behavior such as dissatisfaction statements or behaviors (Mangold \& Faulds, 2009) and patterns of Internet usage (Ross et al., 2009). These differences and importance are such that researchers are urged to treat social media as a distinct research area (Hu \& Kettinger, 2008).

Social media is "a group of internet based applications that builds on the ideological and technological foundations of Web 2.0, and it allows the creation and exchange of user-generated content" (Kaplan \& Haenlein, 2010, p.61). It is defined as the online technologies and practices which people use to share knowledge and opinions. This definition is also supported by Rheingold (1993) who postulates social media to be the "social aggregations that emerge from the Net when enough people carry on those public discussions long enough, with sufficient human feelings, to form webs of personal relationships in Cyberspace."

To grasp the concept of social media two related concepts are fundamental: Web 2.0 and User Generated Content (UGC). "Web 2.0" was mainly used in 2004 to describe a new method in which application programmers and end-users could utilize the World Wide Web. It means 
that Web 2.0 is a platform in which software and content are not produced and published by individual companies and people, but are produced and developed by different participants in a continuous and collaborative manner. UGC represents all the ways by which users create content and use social media on the technological ground of Web 2.0. UGC, which achieved broad popularity in 2005 , is like an umbrella term that contains various forms of media content that are publicly available and created by end-users from text to video and audio materials (Kaplan \& Haenlein, 2010). Based on these definitions, social media contains a broad array of Internetbased applications but it is mostly coined with applications such as YouTube, Wikipedia, Facebook, and Second Life.

Due to the advantages of social media in connecting businesses to end-consumers directly, in a timely manner and at a low cost (Kaplan \& Haenlein, 2010), in influencing customer perceptions and behavior (Williams \& Cothrell, 2000), and in bringing together different likeminded people (Hagel \& Armstrong, 1997; Wellman \& Gulia, 1999), it has become the center of attention in different industries. The much higher level of efficiency of social media compared to other traditional communication channels prompted industry leaders to state that companies must participate in Facebook, Twitter, MySpace, and others, in order to succeed in online environments (Kaplan \& Haenlein, 2010). Thus, more industries try to benefit from social media as they can be used to develop strategy, accept their roles in managing others' strategy or follow others' directions (Williams \& Williams, 2008).

In joining social media, people fulfill their need for belongingness and their need for cognition with those who have shared norms, values and interests (Gangadharbhatla, 2008; Tardini \& Cantoni, 2005). Feeling of being socially connected is stated as a central element in one's psychological sense of community (Sarason, 1974). Although it is asserted that these 
feelings of belongingness would be weaker due to the absence of physical co-presence and lack of proximity in such environments (Constant et al., 1996; Granovetter, 1973), it has been shown that weak ties are capable of bridging people (Wellman, 1997) and encouraging member's engagement in communities to reach deep and intimate levels (Tardini \& Cantoni, 2005). This is supported by Rheingold (1991, p.415) who stated: "People are going to do what people always do with a new communication technology: use it in ways never intended or foreseen by its inventors, so turn old social codes inside out and make new kinds of communities possible." Basically, taking advantage of the strong capabilities of social media, people contribute, create and join communities to fulfill needs of belongingness, being socially connected and recognized or simply enjoying interactions with other like-minded members. So, social media and community are concepts that should be explored together.

\subsection{Brand community}

Relationship marketing, which focuses on creating and maintaining long term customer relationships instead of emphasizing individual transactions, was introduced as a competitive advantage and strategic resource for the firm (Webster, 1992). Since maintaining one-on-one relationships with customers is not always efficient and easy to manage, brand communities were introduced as a solution for serving customers. Brand communities execute important tasks on behalf of the brand. For instance, brand communities support sharing information, perpetuating the history and culture of the brand, and providing assistance to consumers. Brand communities also provide social structure to customer-marketer relationships and greatly influence customer loyalty (Muniz \& O’Guinn, 2001).

A brand community is a "specialized, non-geographically bound community, based on a structured set of social relations among admirers of a brand” (Muniz \& O'Guinn, 2001, p.412) 
and it represents a form of association embedded in the consumption context positioned around one product. These communities are composed of its member entities and their relationships and are identified by their commonalities which help people share essential resources, i.e. cognitive, emotional or material in nature. However, the most important entity shared among members of such community happens to be the "creation and negotiation of meaning" (McAlexander, Schouten, \& Koenig, 2002, p.38). Many scholars studied this topic conceptually and empirically to understand the dimensions and factors shaping such communities (e.g., Granitz \& Ward, 1996; Holt, 1995; Muniz \& O’Guinn, 1996, 2001).

Similar to social media, consumers have their own motivations for joining brand communities. Brands fulfill important psychological and social needs by expressing who a person is and what group the person aligns oneself with (Elliott \& Wattanusuwan, 1998). It is believed that consumers join brands communities to identify themselves with brands so that their social needs of being identified as persons with appropriate self-identity are met. In their own ways, consumers search for the symbols or signs in the communities which help them decipher who they want to be and how they really want to be identified by others. Pierce's semiotic elements constitute an iconic interrelationship where the sign resembles the objects (Grayson \& Martinec, 2004). Schembri, Merrilees, and Kristiansen (2010) show that identification of this type of inter-relationships is aspirational since consumers want self-association with signs which are desirable to them. In consuming brands such as Ferrari and BMW, the interpretant assumes the symbolic meaning as a part of self. Furthermore, brand communities have a potential advantage of gathering customers together and back into conversations, which enable them to obtain information about the brand from various sources (Szmigin \& Reppel, 2001). Companies also have incentives to enhance and support brand communities. Today, more firms are realizing 
the advantages of online brand communities, which include the opportunity for effective communications with their customers and obtaining valuable information. These communities not just provide an additional communication channel, but a possibility of establishing linkages with devoted users (Anderson, 2005). Customers could be a valuable source of information for companies. Von Hippel (2005) posits that already existing customers can be a rich source of innovative ideas and thereby could lead to a chain of actions that might produce the right product or product modifications. Companies like Dell and Cisco Systems transformed suppliers and customers into members of their corporate communities, thereby enabling exchanges of information and knowledge. Furthermore, Schau, Muniz, and Arnould (2009) identified practices in brand communities that create value for both companies and consumers. McAlexander, Schouten, and Koenig (2002) show that through participation in brand-fests, companies are able to manage and increase the feelings of integration into the brand community (Jeep) and positive feelings about the brand and product category. It has also been shown that participants derive social and hedonic values which they cherish as an additional benefit for their efforts. According to gift giving theory (Sherry, 1983), customers perceive these social and hedonic values as a gift, without pushing for direct reciprocity, thereby a sense of indebtedness and goodwill on their part would be enhanced that eventually increases their loyalty.

The initial concepts of offline brand communities had a geographical constraint, in that they needed customers to be physically present, and were the main backbone of research (McAlexander, Schouten, \& Koenig, 2002; Muniz \& O’Guinn, 2001). Today, the concept of brand community is tied with media. Brands transcend geography because media transcend geography (Muniz \& O’Guinn, 2001), and technology made the constraint of geography almost irrelevant. The use of mobile phones, internet, and television made people closer than ever 
before. The role of social media therefore holds the key for brands to get existing and potential customers together in order to create an environment which nourishes the bond between customer and brand and to find new ways to foster this relationship, all without the constraint of geography (Kang et al., 2007). Therefore, with the emergence of new technologies, internet and social media, it is imperative for businesses and customers to find ways to exploit the benefits of both technology and brand community. This results in establishing online brand communities.

\subsection{Social media based brand communities}

The combination of both brand community and social media leads to a concept that we call social media based brand community which is a subset of the broader concept of "virtual communities" or online brand communities; but the main differentiator is their platforms. The core platform of social media is Web 2.00 plus User Generated Content.

Originally brand communities were established on the Web 1.0 platform, on companies' portals or initiated by customers (Jang, 2008). However, with the popularity of social media websites, several companies are using social networking sites to support the creation of brand communities (Kaplan \& Haenlein, 2010; Muniz \& O' Guinn, 2001). Brands such as Jeep with famous offline brand communities (Schau et al., 2009) try to connect with their customers and enhance their brand communities on social networking sites such as MySpace and Facebook. These sites provide the user with a sense of freedom and allow them to converse in various languages, topics and issues, which foster an environment that allows for the free flow of information. People join them and other such sites and use words, videos, pictures, and avatars to stay in touch with their friends, make new friends, make plans with them, have fun and flirt with them, exchange pleasantries and argue, engage in intellectual discourse, conduct commerce, exchange knowledge, share emotional support, brainstorm, gossip, feud, fall in love, find friends, 
play games, create a little high talk and a lot of idle talks (Rheingold, 1991; Lenhart \& Madden, 2007). The communities that are formed for the purpose of sharing information rather than for mere commercial reasons exert the greatest influence on members' opinions and purchase intentions (Algesheimer, Dholakia, \& Herrmann, 2005).

Unlike traditional media where individuals consume content passively, content is created by community members through active participation in social media based brand communities. This active creation of content shapes the character of the community and also determines the influences of users and participants on each other (Werry, 1999; Bagozzi \& Dholakia, 2002). Moreover, since digital environments facilitate the archiving of past content inexpensively, these communities come to represent an aggregation of collective expertise on individual topics, difficult to match elsewhere, and create a capital of knowledge, increasing its value for all members. Next, we explore the effects of social media based brand communities on community elements, value creation practices, brand trust and loyalty.

\section{Development of the model and the hypotheses}

\subsection{Effects of social media based brand community on community communalities}

Community has been a topic of debate among social scientists and philosophers of the nineteenth and early twentieth century and contemporary contributors (Dewey, 1927; Durkheim, [1893] 1933; Lasch, 1991). After a review of the sociology literature, Muniz and O'Guinn (2001) identify three core components or markers of a community; shared consciousness of kind, shared rituals and traditions, and moral responsibility or obligations to society.

Shared consciousness of kind: For Gusfield (1978), one important element in a community is "consciousness of kind" which is the shared intrinsic connection felt among community members. It is a way of thinking that is greater than shared attitudes or perceptions and reflects a 
collective sense of difference from other members not in the same community. Weber (1978) describes it as a shared knowing of belonging. Muniz and O'Guinn (2001) found that members of a community felt a strong connection with one another and they termed it as "they sort of know each other" even if they have never met. This is the central facet of a brand community. They found that through processes of legitimacy and oppositional brand loyalty members of a brand community perpetuate their consciousness of kind. The former refers to the process of differentiating between the true members of a community and those who are not, and the latter refers to the process through which members of a brand community identify what the brand is not and who the brand community members are not. These notions are also supported by other researchers (Englis \& Solomon, 1997; Wilk, 1996).

McAlexander et al. (2002) and Muniz and O'Guinn (2001) found evidence of shared consciousness in brand communities. More importantly, these feelings of oneness exceed geographical boundaries which show that members felt belongingness to a large imagined community. Especially the role of computer mediated communications such as the World Wide Web is very important. They also found several websites that echoed the feeling of shared consciousness of kind such as "made by Saaber for another Saaber... to enjoy," and "Saab Spirit," or "The cult of Macintosh." This demonstrates that members are able to identify the significant social category of Saab or Macintosh.

Shared Rituals and Traditions: These are one of the factors which unite the members of a community and represent vital social processes that bring and keep them together. This helps the meaning of the community be transmitted within and beyond the community (Muniz \& O'Guinn, 2001). Rituals and traditions are a symbolic form of communication that, owing to the satisfaction that members of the community experience through its repetition, is acted out over 
time in a systematic fashion. Through their special meaning and their repetitive nature, rituals contribute significantly to the establishment and preservation of a community's collective sense of self, which plays a role in building community identity. Rituals stabilize this identity by clarifying expected roles, delineating boundaries within and without community, and defining rules so that members know that "this is the way our community is" (Wolin \& Bennett, 1984). The inculcation of history keeps communities vital and their culture alive. Celebrating and admiring the history of a brand community helps distinguish between a true believer and the opportunistic one (Muniz \& O'Guinn, 2001).

Muniz and O'Guinn (2001) and McAlexander et al. (2002) found shared rituals and traditions between brand community members and marketers both in computer mediated environments and in face-to-face contexts. Community members reinforce culture, history, and rituals of the community through processes of celebration of brand history, storytelling, advertising, and shared experiences. Also, most virtual communities create and use shared conventions and language (e.g., jargon, emoticons, or acronyms), maintain social roles, establish boundaries, enact rituals, show commitment to communal goals, and follow norms of interaction.

Moral Responsibilities/Obligations to Society: This community marker is a felt sense of duty or obligation to the community as a whole as well as to its members (Muniz \& O'Guinn, 2001). Moral responsibility has two main functions in communities which make it very important. First it supports community survival through reasoning and recognizing what is right and what is wrong in the community, which results in integrating and retaining members. Second, moral responsibility makes members seek out help from each other in their consumption behavior by disseminating information. Muniz and O'Guinn (2001) and McAlexander et al. (2002) found that moral responsibility manifested itself in their communities. Furthermore, 
reasoning and disseminating information are highly significant in computer mediated environments in which capabilities of media support sharing information.

Thus, ethnographic evidence supports that community communalities are enhanced in brand communities. We are looking for support that such communalities are positively affected in brand communities established on social media, and believe that the main role of social media is to connect people and facilitate sharing information and meaning. As Rheingold (1991) stated people use the new technology to do what they always did. Furthermore, our approach is quantitative and different from previous ones. So we propose the following hypotheses:

H1: Social media based brand community positively influences: a) consciousness of kind among community members, b) shared rituals and traditions, and c) sense of moral responsibility

\subsection{Value creation practices}

A new stream in the literature regards customers not as mere recipients of the products and values of the firm but as co-creators of value, competitive strategy and the firm's innovation processes (Franke \& Piller, 2004; Schau et. al., 2009). With a meta-analysis, Schau et al. (2009) identified four categories of practices through which customers co-create value in brand communities: social networking, impression management, community engagement, and brand use. They assert that people in brand communities are involved in such value creation practices that work together both to enhance the value people realize and to promote the collective health and welfare of social bodies centered on the brands. We believe that brand communities, manifested by their three markers, positively influence these value creation practices. In fact, we argue that the three community communalities positively affect value creation practices especially in the context of social media which enhance communication, information dissemination and the capability of members to be in touch with each other. We elaborate more 
on these issues.

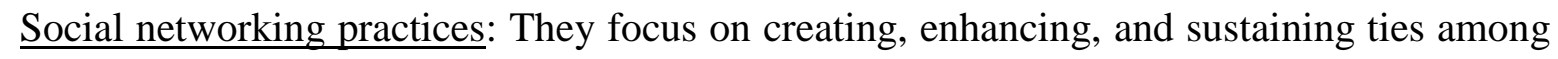
brand community members (Schau, Muniz, \& Arnould, 2009). Welcoming, empathizing and governing are different social networking practices, which enhance similarities among members and homogeneity of brand communities (Schau, Muniz, \& Arnould, 2009). We believe social networking practices to be fostered by the community markers (i.e., shared consciousness, rituals and traditions, and obligations to society). Schau et al. (2009) bring exactly the same example (field note) for supporting social networking practices that Muniz and O'Guinn (2001) brought for supporting shared consciousness. This implies that these concepts are highly related; moreover, in our context, social media could foster such practices as welcoming, empathizing and governing. However, there is no empirical support for it.

Community engagement practices: These reinforce members' escalating engagement with the brand community (Schau et al., 2009). It includes practices such as milestoning and documenting important events in the brand community, and evolving cohesive personal brand narratives. In our view, the concept of engagement goes beyond community participation; it is the process of working collaboratively with relevant partners who share common goals and interests. Although some researchers believe that the Internet, the World Wide Web and in general the new technologies make people increasingly detached from meaningful social relationships and less likely to engage the community as they spend more time online (Davis, 2001; Gackenbach, 1998; Turkle, 1996), others reject this idea and say that "being wired" which they refer to being connected online has the potential to foster and build social associations and encourage community building (Dertouros, 1997). In particular the individuals who use internet communities to explore interests and gather data are found to be more, rather than less, socially 
engaged (Shah, Holbert, \& Kwak, 2000). Thus we believe that communities in the context of social media have the capability to foster engagement.

Impression management practices: They are "activities that have an external, outward focus on creating favorable impressions of the brand, brand enthusiasts and brand community in the social university beyond the brand community" (Schau, Muniz, \& Arnould, 2009, p34). It includes practices such as evangelizing and justifying through which customers preach the brand, share good news about it and bring some arguments to encourage others to use the brand. Online communities foster impressionable facts about the brand through word-of-mouth communications and by sharing personal experiences. Consumers engage in these activities for altruistic nature or to attain higher status (Dichter, 1966; Gatignon \& Robertson, 1986), but Kozinets et al. (2010) found that these intentions are more complex. Whatever their motivation, members of a community are involved in managing impressions activities. We believe that these activities are not only observable in social media communities, but are enhanced by the capabilities of social media.

Brand use practices: This relates to the member's tendency to help other members with newer, improved and enhanced ways to use the focal brand. These basically include the information given by one member to another with regards to customizing the product for better applicability to their needs. They also relate to feelings of one member towards helping or assisting other members who are relatively new to the community. Brand use practices include grooming, customizing, and commoditizing. All these activities results in enhanced uses of the focal brand (Schau et al., 2009). Social media could foster these activities through keeping in touch brand devotees and other members and facilitating their information and resource sharing. In addition to these explanations about value creation practices, we believe that brand 
community markers directly affect value creation practices within the brand community. Moreover, regarding the enabling role of social media in fostering and facilitating communication, information access and networking, the embeddedness of such brand communities in social media contexts results in the enhancement of value creation practices.

The stronger the feelings of shared consciousness, shared rituals and traditions and obligations to society, the more members of a community and the company feel united, close to each other and motivated which enhance collaborative value creation practices. For example, if members consider themselves highly obligated to society, they are more likely to preach and evangelize the brand, help each other better use the branded products, or try to enhance and sustain their ties, all of which are value creation practices. It was also shown that shared consciousness enhances interpersonal ties in a group and increases the willingness to share information and resources with other members, to provide support and to commit to goals identified by the group (Walther, 1996; Wellman, 1999). Thus, we hypothesize that community markers positively affect value creation practices in the context of social media based brand communities:

H2: Social networking practices are positively influenced by the a) shared consciousness of $k i n d, b)$ shared rituals and traditions, and c) sense of moral obligations of members of the community.

H3: Community engagement practices are positively influenced by the a) shared consciousness of kind, b) shared rituals and traditions, and c) sense of moral obligations of members of the community.

H4: Impression management practices are positively influenced by the a) shared consciousness of kind, b) shared rituals and traditions, and c) sense of moral obligations of members of the community.

H5: Brand use practices are positively influenced by the a) shared consciousness of kind, $b$ ) shared rituals and traditions, and c) sense of moral obligations of members of the community. 
These hypotheses are depicted in Figure 1, which provides the model to be tested.

[Figure 1]

\subsection{Effects of value creation practices on brand trust and brand loyalty}

Brand community researchers agree that one of the main functions, if not the main one, of a brand community is to make customers loyal to the brand (Muniz \& O'Guinn, 2001; McAlexander \& Schouten, 1998; McAlexander et al., 2002; Schau et al., 2009; Zhou et al., in press). However, despite qualitative evidence it is still unclear how the process of being more loyal happens in brand communities. Like researchers who refer to the power of online communities as a social structure, in building and enhancing trust and loyalty (Ba, 2001; Walden 2000), we argue that social media based brand communities enhance brand loyalty through the enhancement of brand trust. In fact, value creation practices affect brand trust through three mechanisms, enhanced by capabilities of social media, and brand trust increases brand loyalty. Thus, brand trust would have a mediating role.

Brand trust is "the willingness of the average consumer to rely on the ability of the brand to perform its stated function" (Chaudhuri \& Holbrook 2001, p82). This notion is more prominent in situations of uncertainty, information asymmetry and fear of opportunism; thus, the role of trust is to decrease uncertainty and information asymmetry and make customers feel comfortable with their brand (Chiu, Huang, \& Yen, 2010; Doney \& Cannon, 1997; Gefen, Karahanna, \& Straub, 2003; Moorman, Zaltman, \& Deshpande, 1992; Pavlou, Liang, \& Xue, 2007). One of the mechanisms for value creation practices to enhance trust is based on information dissemination. In all practices, e.g., evangelizing, customizing, welcoming, justifying and documenting (Schau et al., 2009), information passes among members from how to better use the branded products to personal information and stories about the brand. Such information sharing reduces uncertainty 
and information asymmetry, and increases predictability of brand actions (Ba, 2001; Lewicki \& Banker, 1995). Furthermore, the platform of social media facilitates the process of information dissemination. In the literature, repeated interaction and long term relationships are introduced as keys to building trust (Holmes, 1991; Wang \& Emurian, 2005). All value creation practices increase the level of interactions between consumers and the product, the brand, other customers and marketers, all of which are elements of a brand community (McAlexander et al., 2002). The placeless and comprehensive nature of social media based brand communities facilitate long term, close contacts without the loss of relationships that often accompanies offline environments (Ba, 2001). These enhanced relationships results in brand trust.

Trust also involves a "calculative process" (Doney \& Cannon, 1997, p37) related to the value people receive from their relationships. So if people realize the utilitarian and hedonic values of their brand their trust would increase. In brand communities and through value creation practices, people develop close relationships and draw values from their long term interactions, which makes them trust and love the brand (Carroll \& Ahuvia, 2006; Zhou et al., in press). Based on these arguments we hypothesize:

H6: Social networking practices positively influence brand trust

H7: Community engagement practices positively influence brand trust

H8: Impression management practices positively influence brand trust

H9: Brand use practices positively influence brand trust

A great deal of research supports the positive effect of trust on loyalty in online or offline contexts (Chaudhuri \& Holbrook, 2001; Chiu, Huang, \& Yen, 2010; Harris \& Goode, 2004; Kim, Chang, \& Lee, 2011; Zhou et al., in press). Brand trust is one of the most important antecedents of brand loyalty; however in the brand community literature there is little emphasis 
on this relationship, so we hypothesize:

H10: Brand trust positively influences brand loyalty

Figure 1 shows the complete model of how brand community affects brand loyalty. As depicted, brand trust has a mediating role between the effects of value creation practices and brand loyalty.

\section{Method}

\subsection{Subjects and procedure}

Since we test our model in the context of social media based brand communities, the target population is all members of brand communities on social networking websites. We used the screening condition that respondents had to be members of such brand communities. The study was introduced as an "opinion survey" and participants were asked to list the name of the community they associate themselves with; are a member of any brand community or any social networking site and to consider them when responding to questions. This is important because the study aims to investigate the effects of such communities on members, regardless of a specific product, brand or social media. The questionnaires were distributed through social network websites such as Facebook, MySpace, and Twitter. Several posts were included in these heavy traffic websites along with email distribution lists. This method of data collection, which is consistent with previous online studies (Bagozzi \& Dholakia, 2006; Steenkamp \& Geyskens, 2006) generated 441 valid responses ( $41.1 \%$ female). The age range varied between 18 and 55 .

\subsection{Measures}

All constructs were measured with multiple item-scales. Some items were adopted from the related literature and modified to suit the study, and some were developed from the literature (Appendix). A pretest with 30 respondents was conducted to validate the constructs. 
Brand community: As we measured it in a social media context, we first asked respondents to answer the items based on their experiences with brand communities on social networking sites of which they are members. A set of six items on a 5-point Likert scale measured this construct (Srinivasan, Anderson, \& Ponnavolu, 2002). Based on the validity of this scale, we adopted it with some modifications to suit our context. The Cronbach's alpha is 0.72 .

Shared consciousness, shared rituals and traditions, and obligations to society: The scales were derived from the definitions given by Muniz and O'Guinn (2001) and consisted of two items each. The items were tested in a three factor confirmatory model and an acceptable fit was obtained, with Cronbach's alphas of $0.72,0.73$ and 0.75 respectively. The items were also successfully tested for discriminant validity. The average variances extracted for the scales were $0.78,0.79$ and 0.65 respectively, showing convergent validity.

Social networking: Eight 5-point Likert items measured this construct. The scale was developed for use with an online store (Hsieh, Chiu, \& Chiang, 2005). However, since the scale measures the same construct as in the original study, it was used with a slight modification. The scale has a reliability of 0.78 . Further analyses provided evidence of convergent validity. The average variance extracted is 0.65 .

Community engagement: Four 5-point Likert items measured this construct. The items measured the degree to which a person is involved with a community of brand users due to intrinsic benefits of the activity (Algesheimer, Dholakia, \& Herrmann, 2005). The scale reliability is 0.71 and the average variance extracted is 0.64 .

Brand use: Three 5-point Likert-type statements measured the degree to which a member of a community gets useful information about the brand's use. The items were constructed from the definition of brand use practices given by Schau, Muniz and Arnould (2009). The average 
variance extracted is 0.61 and the Cronbach's alpha is 0.70 .

Impression management: It is derived from the definition given by Schau, Muniz and Arnould (2009). The scale consists of three 5-point Likert items. The average variance extracted is 0.63 and the Cronbach's alpha is 0.71 .

Brand trust: It was measured as a three-item index based on the four item index originally developed by Chaudhuri and Holbrook (2001) using a 5-point rating of agreement with three statements: "I trust my brand to give me everything I expect out of it," "I rely on this brand," and "My brand never disappoints me." The Cronbach's alpha for this index is 0.71 .

Brand loyalty: It was derived from Delgado-Ballester, E., Manuera-Aleman, \& YagueGuillen (2003). The three items are measured on a 5-point Likert scale characterized by a reliability of 0.84 and an average variance extracted of 0.57 .

\section{Results}

Structural equation modeling with the AMOS graphical software program was used to test the model and hypotheses shown in Figure 1. The goodness-of-fit of the overall model was assessed with the chi-square test, the root mean square error of approximation (RMSEA), and the comparative fit index (CFI) (Bentler, 1990; Marsh, Balla, \& Hau, 1996). Satisfactory model fits are indicated by non-significant chi-squared tests, RMSEA value less than 0.08 and CFI values greater than or equal to 0.90 .

Internal consistency. Two measures were used to evaluate the internal consistency of the constructs. Reliability is identified by Cronbach's alpha with a minimum of 0.70 (Cronbach, 1970; Nunnally, 1978) and the average variance extracted (AVE) which estimates the amount of variance captured by a construct's measure relative to random measurement error (Fornell \& Larcker, 1981). An AVE greater than 0.50 is considered to support internal consistency (Bagozzi 
\& Yi, 1988). All AVEs are greater than 0.50. Table 1 also shows descriptive statistics for the constructs and their reliability measures which are all above 0.70 .

[Table 1]

Unidimensionality. The evaluation of unidimensionality of the proposed scales was assessed by performing exploratory factor analysis (EFA). Factors were extracted based on eigenvalues greater than 1 . In addition they were required to have a significant factor loading greater than 0.4 and a high total variance explained component. Based on the results only one factor was extracted for shared consciousness, rituals and traditions, obligations to society, impression management, community engagement, brand use, brand loyalty, brand trust, social networking and online brand communities constructs.

A total of 10 constructs were formed based on their eigenvalues. Bartlett's test of Sphericity and 'Kaiser-Meyer-Olkin' (KMO) measure of sampling adequacy are provided in Table 2. Bartlett's Test of Sphericity determines whether there is a high enough degree of correlation among the variables. Table 2 shows that the test is significant $(p<.001)$. The KMO stat as indicated Table 2 is 0.85 which is greater than the minimum of 0.5 indicating a good degree of correlation. Hence the test reveals a meaningful factor analysis and principal component analysis can be carried out. The total variance explained by the 10 factors is $66.8 \%$.

[Table 2]

In the EFA, we found that the items "The community allows direct user input or posting to site" (ob1), "The brand community keeps in touch with me with notifications" (sn1), "The community provides with me product information" (sn4), "I share my opinions on the community" (sn8) and "I benefit from following the community's rules" (ce1) did not have high enough loadings on their respective factors. Hence they were eliminated from further analysis. 
CFA Results. Next we conducted confirmatory factor analysis (CFA). Poor factor loadings were found for two items of brand community measures (ob2 with loading .05, and ob3 with loading 0.12 , both are less than 0.4 ) so we dropped them out and run the model again. We found good fit indices for the CFA model including all latent variables assuming they are correlated (further analysis shows this is a true assumption since correlations among all variables are significantly greater than zero; Table 3); $\chi 2=478.0, p=.000, \mathrm{RSMEA}=0.032, \mathrm{CFI}=0.97$, $\mathrm{GFI}=0.93, \mathrm{RMR}=0.024$. Except the Chi square which is sensitive to sample size and not a good indicator, all other statistics show a good fit for the CFA model (Bagozzi \& Yi 1988). Table 3 shows factor loadings and $\mathrm{R}^{2}$ for each item (see Appendix for the items).

[Table 3]

Discriminant validity. Discriminant validity is achieved when the correlations between the constructs differ significantly from 1 or when Chi-square difference tests indicate that two constructs are not perfectly correlated. As a test of discriminant validity, the correlations among the latent variables were checked to determine if they are significantly different from 1 . Table 4 shows the result for the discriminant validity, confirming the validity of all constructs.

[Table 4]

Convergent validity. Referring to the CFA model, since all the factor loadings are above 0.5, convergent validity is supported (Steenkamp \& Geyskens, 2006).

\subsection{Structural model estimation}

With respect to the fit statistics for the full model $(\chi 2(347)=572.8, \chi 2 / \mathrm{df}=1.65, p=0.000)$, the chi-square is significant $(\mathrm{p}<0.05)$, which is usually the case for large sample sizes, and the $\chi 2 /$ df is less than 2 . All other statistics are within acceptable ranges including RMSEA=0.038, $\mathrm{CFI}=.95, \mathrm{GFI}=0.92, \mathrm{IFI}=0.95, \mathrm{RMR}=0.28$ (Bagozzi \& Yi, 1988). 
We found strong support for the effects of social media based brand community on the three markers of community, i.e., shared consciousness, shared rituals and traditions, and obligations to society. The $\beta$ values are respectively: 1.27, 1.30, and 1.05. All of these relationships are significant at the 0.001 level, providing support for $\mathrm{H} 1 \mathrm{a}, \mathrm{H} 1 \mathrm{~b}$ and H1c. Figure 2 summarizes these and other results.

[Figure 2]

Shared consciousness has a significant effect on social networking practices $(\beta=0.29$, $p<.01)$ supporting $\mathrm{H} 2 \mathrm{a}$. It has a positive, significant effect on community engagement and brand use practices at $\mathrm{p}<.05$ level, with $\beta=0.21$ and $\beta=0.14$, respectively, which support $\mathrm{H} 3 \mathrm{a}$ and $\mathrm{H} 5 \mathrm{a}$. However, the effect of shared consciousness on impressions management (H4a) is not supported $\beta=0.07, p=0.36$.

The effects of shared rituals and traditions on value creation practices were hypothesized in $\mathrm{H} 2 \mathrm{~b}, \mathrm{H} 3 \mathrm{~b}, \mathrm{H} 4 \mathrm{~b}$ and $\mathrm{H} 5 \mathrm{~b}$. We found support for all these hypotheses at $p<0.01$. The effects of shared rituals and traditions are positive and significant on: social networking $(\beta=0.33)$, community engagement $(\beta=0.37)$, impressions management $(\beta=0.33)$, and brand use practices $(\beta=0.26)$.

As expected, obligations to society has significant positive influences on all the four constructs of value creation practices (social networking, community engagement, brand use practices, and impressions management) in support of $\mathrm{H} 2 \mathrm{c}, \mathrm{H} 3 \mathrm{c}, \mathrm{H} 4 \mathrm{c}$ and $\mathrm{H} 5 \mathrm{c}$ with significance levels of $p<0.001$, and $\beta$ values of $0.40,0.47,0.43$ and 0.39 respectively.

The effects of value creation practices on brand trust were hypothesized in H6 to H9. The effects of social networking and community engagement practices on brand trust (H6 and H7) are not supported with $\beta$ s ( $p$-values) respectively: 0.06 (0.65), and $0.12(0.28)$. However, the 
effect of impression management on brand trust $(\mathrm{H} 8)$ is significant at $p<0.001$ with $\beta=0.31$. The effect of brand use practices on brand trust (H9) is significant $(\beta=0.29, p<.05)$. As predicted by $\mathrm{H} 10$, the effect of brand trust on brand loyalty is significant and positive $(\beta=.86, p<.001)$.

The findings show that brand trust fully mediates the effect of brand use and impressions management practices on brand loyalty. To confirm that brand trust fully mediates these effects we tested another model with brand trust as a partial mediator. We added direct relationships from the four value creation practices to brand loyalty in the current model (Figure 3).

\section{[Figure 3]}

We tested this model, but none of the new relationships were significant and the model fit did not improve $(\chi 2=570.4, \mathrm{df}=343, \mathrm{RMSEA}=0.039, \mathrm{CFI}=0.95, \mathrm{GFI}=0.92, \mathrm{IFI}=0.95)$. This implies that brand trust fully mediates the effects of the two value creation practices, i.e., brand use and impressions management, on brand loyalty.

\section{Discussion and implications}

This study looked at the fast growing phenomenon of brand communities established on social media. Drawing on the literature on brand community, we proposed a model of the effects of brand community on shared community markers, value creation practices and the way they convert to brand loyalty through brand trust. Using SEM we found support for the model and most of our hypotheses. We found that brand communities established on social media enhance feelings of community among members and contribute to creating value for both members and the company. Furthermore, the model shows how brand loyalty is increased in brand communities. The whole model shows that value creation practices enhance loyalty through brand trust as a mediator.

Contrary to expectations, only two of the four value creation practices (brand use and 
impressions management) contribute to brand trust. There is one possible explanation for this finding. As Schau et al. (2009, p37) argue, "Practices operate like apprenticeship," which means that "their effects evolve over time as consumer engagement deepens and practices are integrated." Thus, it is possible that the effects of practices in social media based brand communities may not have evolved enough to significantly affect brand loyalty. This makes sense because the concept and prevalence of social media is new and its effects are emerging as time goes on and more people engage in the activities of social media. This difference might be due to the difference in the nature of practices as well. For example the effects of brand use practices, which mainly are about better consumption of the focal brand, are more immediate than social networking practices that need more time to develop.

The effect of shared consciousness on impressions management $(\mathrm{H} 4 \mathrm{a})$ was not significant as well. This has two possible explanations. First, it is possible that merely having a shared consciousness or feeling of a community does not lead to actively preaching and evangelizing the community and its ethos. For doing so, consumers need to have more incentives and be more obligated to society. As our results show, feelings of obligations to society have significant and strong effects on impressions management. This makes more sense considering the fact that having a large number of brand community members in social media weakens the ties among users. Second, Muniz and O'Guinn's (2001) legitimacy, an element of shared consciousness, exists for some brand communities but not for others. For example, they did not find evidence of legitimacy for the Macintosh community. Since we aggregated data from different communities, it is possible that existence and nonexistence of such elements in different communities neutralized each other's effects so that we don't have large enough effect sizes to reach significance. Focusing on specific brand communities based on social media will address this 
issue, which is an avenue for future research.

Our study contributes to existing brand community knowledge in several ways and has theoretical implications. First, we extended the concept of brand community to social media and created more insights on this important phenomenon. Recently, the uniqueness of social media has been acknowledged by researchers as a distinct research domain (e.g., Hu \& Kettinger, 2008), so our study provides more insights into this domain. Second, we developed a nomological network that shows how a community affects community markers, practices, brand trust and brand loyalty; then we tested it in the context of social media. Although, previous researchers showed qualitatively the existence of such effects in brand communities (Muniz \& O'Guinn, 2001; McAlexander et al., 2002), we modeled these effects in online environments, and tested the model quantitatively. Our findings explicitly show how practices could affect brand loyalty as well as their relative weights. For example, we show that brand communities affect loyalty through brand use practices. However, in interpreting the results we should be cautious because of the apprenticeship effects of such practices. Third, we created new scales to measure some of the constructs which could be used by other researchers.

This work has important practical implications for managers. The vast reach, low cost and popularity of social media are prompting all brand managers to take advantage of such characteristics, so that they, almost blindly, want to be on social media. Our findings help them have more insights into this process. First, it shows that brand communities based on social media have the same advantages and benefits as offline brand communities. They positively influence the shared consciousness, shared rituals and obligations to society of community members. Furthermore, they result in enhancing value creation practices. Second, our findings show that if managers wish to enhance brand loyalty, they have to promote brand use and 
impressions management practices in their brand communities. Brand use practices refer to disseminating information or other activities that help members more optimally use their branded product; impressions management involves practices that manage external impressions and images of the brand (Schau et al., 2009). Obviously these activities could be promoted easily with social media capabilities of sharing information and connecting people. Another important observation from the model is the relative importance of obligations to society. The path coefficients from obligations to society to value creation practices are larger than the coefficients of other paths. This implies that marketers could enhance value in communities by emphasizing obligations and commitment to society. The more members feel committed and obligated to society the more they would get involved in practices that create value for the community.

\section{Limitations and future research}

Despite these contributions, we acknowledge the limitations of this research and accordingly propose new avenues for research. First, we showed that brand communities based on social media can enhance feelings of community and value creation practices. Regarding our goals, we mainly concentrated on general notions and concepts in the brand community and social media literatures. However, in the future researchers may consider more variables and factors to produce deeper insights. For example, potential moderators and mediators such as brand type, culture, structure and type of communities as well as the differences in social media platforms functionality and features (Kietzmann et al., 2011) could be investigated.

However, it should be noted that brand communities based on social media might not be easy to manage. In this environment, customers are more powerful than before. They easily can interact, speak and broadcast their ideas to each other while companies would have increasingly less ability to manage the information available about them in the new space (Kaplan \& 
Haenlein, 2010). In addition, consumers may get involved in online complaints with forming protest websites or weblogs if they are dissatisfied, or upset with the brand (Ward \& Ostrom, 2006). Thus, as businesses decide to establish or enhance online social media based communities, they should be cautious about their potential consequences. Accordingly, more research is needed to study and analyze such consequences and introduce effective techniques to manage communities in such environments.

One interesting avenue for research is to investigate the dynamics of brand communities based on social media. For example, we mentioned that the effects of value creation practices evolve over time (Schau et al., 2009); however; we do not know how these effects act over time and how they develop. So we suggest longitudinal studies to enable researchers to follow the changes in the community and compare the results at different times.

\section{Conclusion}

In this article, we demonstrated the effects of brand communities established on the platform of social media on the underlying elements and practices in communities as well as on brand trust and brand loyalty. We believe that due to the importance, uniqueness and rapid growth of social media, marketers and researchers should pay special attention to this phenomenon and examine well established notions and theories in the social media contexts. To sum up briefly, from our findings it seems appropriate to echo the optimism of brand community researchers such as McAlexander, Schouten, and Koenig (2002), Muniz and O'Guinn (2001) and Algesheimer, Dholakia and Herrmann (2005) and to suggest that social media based brand communities offer brand owners the ability to enhance value, brand trust, brand loyalty and feelings of community among members. Marketers may do well to take advantage of the opportunities that such brand communities present. 


\section{Appendix -Summary of measures}

\begin{tabular}{|c|c|c|}
\hline 1 & $\begin{array}{l}\text { Brand } \\
\text { community }\end{array}$ & $\begin{array}{l}\text { Ob1- The community allows direct user input or posting to site. } \\
\text { Ob2- Customers share experiences about products online with other } \\
\text { customers. } \\
\text { Ob3- The community is useful for gathering various information about } \\
\text { the product or the brand. } \\
\text { Ob4- The members of this community benefit from the community. } \\
\text { Ob5- The members share a common bond with other members of the } \\
\text { community. } \\
\text { Ob6- The members are strongly affiliated with other members }\end{array}$ \\
\hline 2 & $\begin{array}{l}\text { Social } \\
\text { networking }\end{array}$ & $\begin{array}{l}\text { Sn1- The brand community keeps in touch with me with notifications. } \\
\text { Sn2- At least some of members of my community know me. } \\
\text { Sn3- I received special treatment after I became a member. } \\
\text { Sn4- The community provides with me product information. } \\
\text { Sn5- The community is concerned with my needs. } \\
\text { Sn6- The community collects my opinions about the services/product. } \\
\text { Sn7- The community recognizes special occasions and sends me } \\
\text { greetings. } \\
\text { Sn8- I share my opinions on the community. }\end{array}$ \\
\hline 3 & $\begin{array}{l}\text { Shared } \\
\text { consciousness }\end{array}$ & $\begin{array}{l}\text { Sc1- An intrinsic connection is felt among the members. } \\
\text { Sc2- A general sense of difference exists from members who are NOT in } \\
\text { your community. }\end{array}$ \\
\hline 4 & $\begin{array}{l}\text { Rituals and } \\
\text { traditions }\end{array}$ & $\begin{array}{l}\text { Tt1- I recollect vital social traditions or rituals specific to the brand } \\
\text { community. } \\
\text { Tt2- I think these traditions contribute towards a specific culture of the } \\
\text { community. }\end{array}$ \\
\hline 5 & $\begin{array}{l}\text { Obligations to } \\
\text { society }\end{array}$ & $\begin{array}{l}\text { Obcoc1- The members of the community assist/advice other members of } \\
\text { the same community in the proper use of the brand. } \\
\text { Obsoc2- The community engages in integrating and retaining members. }\end{array}$ \\
\hline 6 & $\begin{array}{l}\text { Community } \\
\text { engagement }\end{array}$ & $\begin{array}{l}\text { Ce1- I benefit from following the community's rules. } \\
\text { Ce2- I am motivated to participate in the activities because I feel good } \\
\text { afterwards or because I like it. } \\
\text { Ce3- I am motivated to participate in the community's activities because } \\
\text { I am able to support other members. } \\
\text { Ce4- I am motivated to participate in the community's activities because } \\
\text { I am able to reach personal goals. }\end{array}$ \\
\hline 7 & $\begin{array}{l}\text { Impression } \\
\text { management }\end{array}$ & $\begin{array}{l}\text { Im1- Community encourages discussions related to company, brand or } \\
\text { the product. } \\
\text { Im2- Members actively engage in discussions in order to justify their } \\
\text { reasons for their affinity towards the brand. } \\
\text { Im3- Members actively defend/refute the actions of the company's } \\
\text { management. }\end{array}$ \\
\hline
\end{tabular}




\begin{tabular}{|c|c|c|}
\hline 8 & Brand use & $\begin{array}{l}\text { Bu1- Members of my community share useful tips about better uses of } \\
\text { the product or brand. } \\
\text { Bu2- Members of my community share their experiences about their } \\
\text { successful and unsuccessful attempts at customization of the } \\
\text { product. } \\
\text { Bu3- Members of my community monitor and foster the activities } \\
\text { deemed to help community building. }\end{array}$ \\
\hline 9 & Brand loyalty & $\begin{array}{l}\text { L1- I consider myself to be loyal to the brand. } \\
\text { L2- If the brand is not available at the store I would buy the same brand } \\
\text { from some other store. } \\
\text { L3- I am willing to pay more for my brand. }\end{array}$ \\
\hline 10 & Brand trust & $\begin{array}{l}\text { BT1- My brand gives me everything that I expect out of the product. } \\
\text { BT2- I rely on my brand. } \\
\text { BT3- My brand never disappoints me. }\end{array}$ \\
\hline
\end{tabular}

Note: All responses are based on 5-point Likert scales anchored by: $1=$ "Totally disagree" and $5=$ "Totally agree".

\section{References}

Algesheimer, R., Dholakia, U., \& Herrmann, A. (2005). The social influence of brand community: Evidence from European car clubs. Journal of Marketing, 69(3), 19-34.

Anderson, P. H. (2005). Relationship marketing and brand involvement of professionals through web-enhanced brand communities: The case of Coloplast. Industrial Marketing Management, 34(3), 285-297.

Ba, S. (2001). Establishing online trust through a community responsibility system. Decision Support System, 31, 323-336.

Bagozzi, R., \& Dholakia, U. (2002). Intentional social action in virtual communities. Journal of Interactive Marketing, 16(2), 2-21.

Bagozzi, R., \& Dholakia, U. (2006). Open source software communities: A study of participation in Linux user groups. Management Science, 52, 1099-1115.

Bagozzi, R., \& Yi, Y. (1988). On evaluation of structural equation models. Journal of the Academy of Marketing Science, 16, 74-94.

Bentler, P. M. (1990). Comparative fit indexes in structural models. Psychological Bulletin, 107, 238-246.

Brown, S., Kozinets, R. V., \& Sherry Jr., J. F. (2003). Teaching old brands new tricks: Retro branding and the revival of brand meaning. Journal of Marketing, 67, 19-33.

Carroll, B. A., \& Ahuvia, A. C. (2006). Some antecedents and outcomes of brand love. Marketing Letters, 17, 79-89.

Chaudhuri, A., \& Holbrook, M. B. (2001). The chain of effects from brand trust and brand affect to brand performance: The role of brand loyalty. Journal of Marketing, 65, 2, 81-93.

Chiu, C. M., Huang, H. Y., \& Yen, C. H., (2010). Antecedents of online trust in online auctions. Electronic Commerce Research and Application, 9, 148-159.

Constant, D., Sproull L., \& Kiesler, S. (1996). The kindness of strangers: The usefulness of electronic weak ties for technical advice. Organization Science, 7, 119-135.

Cronbach, L. J. (1970). Essentials of psychological testing. New York: Harper and Row. 
Davis, R.A. (2001). A cognitive-behavioral model of pathological Internet use. Computers in Human Behavior, 17, 2, 187-195.

Delgado-Ballester, E., Manuera-Aleman, J. L., \& Yague-Guillen, M. J. (2003). Development and validation of a brand trust scale. International Journal of Market Research, 45, 1, 35-54.

Dertouros, M. L. (1997). What will be: How the new world of information will change our lives. San Francisco: Harper Edge.

Dewey, J. (1927). The public and its problems, New York: Holt.

Dichter, E. (1966). How word-of-mouth advertising works. Harvard Business Review, 16, 147166.

Doney, P. M. \& Cannon, J. P. (1997). An examination of the nature of trust in buyer-seller relationships. Journal of Marketing, 61, 35-51.

Durkheim, E. ([1893] 1933). The division of labor in society, trans. George Simpson, New York: Free Press.

Elliott, R., \& Wattanasuwan, K. (1998). Brands as Symbolic resources for the construction of identity. International Journal of Advertising, 17, 131-144.

Englis, B. G., \& Solomon, M. R. (1997). I am not, therefore, I am: The role of avoidance products in shaping consumer behavior. Advances in Consumer Research, 24, 61-62

Franke, N., \& Piller, F. (2004), Value Creation by Toolkits for User Innovation and Design: The Case of the Watch Market. Journal of Product Innovation Management, 21, 401-415.

Franke, N., \& Shah, S. K. (2003). How communities support innovative activities: An exploration of assistance and sharing among end-users. Research Policy, 32, 157-178.

Fornell, C., \& Larcker, D. F. (1981). Evaluating structural equation models with unobservable variables and measurement error. Journal of Marketing Research, 28, 39-50.

Gackenbach, J. (1998). Psychology and Internet: Interpersonal, Intrapersonal and Transpersonal Implications, San Diego: Academic Press.

Gangadharbhatla, H. (2008). Facebook Me: Collective self-esteem, need to belong and internet self-efficacy as predictors of the I-generations attitudes toward social networking sites. Journal of Interactive Advertising, 8(2), 5-15.

Gatignon, H., \& Robertson, T. S. (1986). An exchange theory model of interpersonal communication. Advances in Consumer Research, 13, 534-538.

Gefen, D., Karahanna, E., \& Straub, D. W. (2003). Trust and TAM in online shopping: An integrated model. MIS Quarterly, 27, 51-90.

Granitz, N. A., \& Ward, J. C. (1996). Virtual community: A socio-cognitive analysis. Advances in Consumer Research, 23, 161-166.

Granovetter, M. (1973). The strength of weak ties. American Journal of Sociology, 78, 13601380.

Grayson, K., \& Martinec, R. (2004). Consumer perceptions of iconicity and indexicality and their influence on assessments of authentic market offerings. Journal of Consumer Research, 31, 296-312.

Gusfield, J. (1978) Community: A critical response. New York: Harper and Row.

Hagel, J., \& Armstrong, A. G. (1997). Net gain: Expanding markets through virtual communities. Boston, MA: Harvard Business School Press.

Hanna, R., Rohm, A., \& Crittenden, V. L. (2011). We're all connected: The power of the social media ecosystem. Business Horizons, 54, 265-273.

Harris, L. C., \& Goode, M. M. H. (2004). The four levels of loyalty and the pivotal role of trust: A study of online service dynamics. Journal of Retailing, 80, 139-158. 
Holmes, J. G. (1991). Trust and the appraisal process in close relationships. In: W. H. Jones, D. Perlman (Eds.), Advances in Personal Relationships 2 (pp.57-104) Jessica Kingsley, London..

Holt, D. B. (1995). How consumers consume: A typology of consumption practices. Journal of Consumer Research, 22(1), 1-16.

Hsieh, Y., Chiu, H., \& Chiang, M. (2005). Maintaining and committed online customer: A study across search-experience-credence products. Journal of Retailing, 81, 75-82.

$\mathrm{Hu}, \mathrm{T}$., \& Kettinger, W. J. (2008). Why people continue to use social networking services: Developing a comprehensive model. In Proceedings, 29th International Conference on Information Systems, Paris, France.

Jang, H., Olfman, L., Ko, I., Koh, J., \& Kim, K. (2008). The influence of online brand community characteristics on community commitment and brand loyalty. International Journal of Electronic Commerce, 12(3), 57-80.

Jin, X. L., Cheung, C. M. K., Lee, M. K. O., \& Chen, H. P. (2009). How to keep members using the information in a computer-supported social network. Computers in Human Behavior, 25, $1172-1181$.

Kang, I, Lee, K. C, Lee, S., \& Choi, J. (2007). Investigation of online community voluntary behaviour using cognitive map. Computers in Human Behavior, 23, 111-126.

Kaplan, A. M., \& Haenlein, M. (2010). Users of the world, unite! The challenges and opportunities of social media. Business Horizons, 53, 59-68.

Kietzmann, J. H., Hermkens, K., McCarthy, I. P., \& Silvestre, B. S. (2011). Social media? Get serious! Understanding the functional building blocks of social media. Business Horizons, 54, 241-251.

Kim, M., Chung, N., \& Lee, C. (2011). The effect of perceived trust on electronic commerce: Shopping online for tourism products and services in South Korea. Tourism Management, 32, 256-265.

Kozinets, R., de Valck, K., Wojinicki, A. C., \& Wilner, S. (2010). Networked narratives: Understanding word-of-mouth marketing in online communities. Journal of Marketing, 74, 71-89.

Lang, B. (2010, September 20). Ipsos OTX study: People spend more than half their day consuming media. Retrieved from http://www.thewrap.com/node/21005

Lasch, C. (1991). The true and only heaven: Progress and its critics, New York: Norton.

Lenhart, A., \& Madden, M. (2007). Social networking websites and teens: An overview. PEW Internet and American Life Project.

Lewicki, R. J., \& Bunker, B. (1995). Trust in relationships: A model of trust development and decline. In Bunker, B., \& Rubin, J. (Eds), Conflict, cooperation and justice (pp.133-173). Jossey-Bass, San Francisco.

Mangold, W. G., \& Faulds, D. J. (2011). Social media: The new hybrid element of the promotion mix. Business Horizons, 52, 357-365.

Marsh, H., Balla, J., \& Hau, K. T. (1996). An evaluation of incremental fit indices: A clarification of mathematical and empirical properties. In Marcoulidesand, G. A., \& Schmacker, R. E. (Eds.) Advanced structural equation modeling: Issues and techniques (pp. 315-353). Mahwah, NJ: Erlbaum.

McAlexander, J. H., Schouten. W. John, \& Koening, F. H. (2002). Building brand community. Journal of Marketing, 66, 38-54. 
McAlexander, J. H., \& Schouten, J. W. (1998). Brand-fests: Servicescapes for the cultivation of brand equity. In Sherry J. F. (Eds) Servicescapes: The concept of place in contemporary markets (pp.377-402). Chicago: American Marketing Association.

Moorman, C., Zaltman, G., \& Deshpande, R. (1992). Relationships between providers and users of market research: The dynamics of trust within and between organizations. Journal of Marketing Research, 29, 314-28.

Muniz, M. A., \& O'Guinn, C. T. (2001). Brand community. Journal of Consumer Research, 27, $412-432$.

Muniz, A., \& Schau, H. J. (2005). Religiosity in the abandoned Apple Newton Brand Community. Journal of Consumer Research, 31, 737-47.

Nunnally, J. C. (1978). Psychometric testing, New York: McGraw Hill.

Pavlou, P. A., Liang, H., \& Xue, Y. (2007). Understanding and mitigating uncertainty in online exchange relationships: A principal-agent perspective. MIS Quarterly, 31, 105-136.

Rheingold, H. (1993). The virtual community. Homesteading on the electronic frontier. MA: Addison-Wesley.

Rheingold, H. (1991). A slice of life in my virtual community. In: Harasim, L. M. (Ed.), Global networks (pp. 57-80). Cambridge, MA: MIT Press.

Ross, C., Orr, E. S., Sisic, M., Arseneault, J. M., Simmering, M. G., \& Orr, R. R. (2009). Personality and motivations associated with Facebook use. Computers in Human Behavior, $25,578-586$.

Sarason, S. B. (1974). The psychological sense of community: Prospects for the community psychology. San Francisco: Jossey-Bass.

Schau, J. H., Muniz, M. A., \& Arnould, J. E. (2009). How brand community practices create value. Journal of Marketing, 73(5), 30-51.

Schembri, S., Merrilees, B., \& Kristiansen, S. (2010). Brand consumption and narrative of the self. Psychology and Marketing, 27, 623-637.

Shah, D., Holbert, L., \& Kwak, N. (2000). Expanding the 'virtuous circle' of social capital: Civic engagement, contentment and interpersonal trust. Paper presented at annual meeting of Association for Education in Journalism and Mass Communication.

Sherry, J. F. Jr. (1983). Gift giving in anthropological perspective. Journal of Consumer Research, 10, 157-168.

Srinivasan, S. S., Anderson, R., \& Ponnavolu, K. (2002). Customer loyalty in e-commerce: An exploration of its antecedents and consequences. Journal of Retailing, 78, 41-50.

Steenkamp, J.B.E.M., \& Geyskens, I. (2006). How Country Characteristics Affect the Perceived Value of a Website. Journal of Marketing, 70, 136-150.

Szmigin, I., \& Reppel, A. E. (2001). Internet community bonding: The Case of macnews.de. European Journal of Marketing, 38, 626- 640.

Tardini, S., \& Cantoni, L. A. (2005). A semiotic approach to online communities: Belonging, interest and identity in websites' and video games' communities. In: Proceedings of IADIS International Conference, 371-378.

Turkle, S. (1996). Virtuality and its discontents: Searching for community in cyberspace. The American Prospect, 24(4), 50-57.

Von Hippel, E. (2005). Democratizing innovation, Boston, MA: MIT Press.

Walden, E., (2000). Some value propositions of online communities. Electronic Markets 10, 244-249. 
Walther, J. B. (1996). Computer-mediated communication: Impersonal, interpersonal and hyperpersonal interaction. Communication Research, 23(1), 3-43.

Wang, Y.D., \& Emurian, H. H. (2005). An overview of online trust: Concepts, elements, and implications. Computers in Human Behavior, 21, 105-125.

Ward, J. C., \& Ostrom, A. L. (2006). Complaining to the masses: The role of protest framing in customer-created complaint web sites. Journal of Consumer Research, 33, 220- 230.

Weber, M. ([1922] 1978). Economy and society. Berkeley, CA: University of California Press.

Webster, F. E. Jr. (1992). The changing role of marketing in the corporation. Journal of Marketing, 56 (October), 1-17.

Wellman, B. (1997). An electronic group is virtually a social network. In: Wellman, B. (Ed.), Culture of the Internet (179-205). Mahwah: Lawrence Erlbaum.

Wellman, B. (1999). The network community: An introduction to networks in the global village. In: Wellman, B. (Ed.), Networks in the global village (pp.1-48) Boulder, CO: Westview.

Wellman, B., and Gulia, M. (1999). Net-surfers don't ride alone: Virtual communities as communities. In Wellman, B. (Ed.) Networks in the global village (pp.331-366) Boulder, CO: Westview.

Werry, C. (1999). Imagined electronic community: Representations of virtual community in contemporary business discourse. First Monday, 4(9).

Wilk, R. (1996), Learning to not-want things. Paper presented at the Association for Consumer Research Annual Conference.

Williams, L., \& Cothrell, J. (2000). Four smart ways to run online communities. Sloan Management Review, 41, 81-91.

Williams, T., \& Williams, R. (2008). Adopting social media: Are we leaders, managers or followers? Communication world, 25(4), 34-37.

Wolin, J. S., \& Bennett, L. (1984). Family rituals. Family process, 23(3), 401-420.

Zhou, Z., Zhang, Q., Su, C., \& Zhou, N. (in press). How do brand communities generate brand relationships? Intermediate mechanisms. Journal of Business Research. 
Figure 1- Model of the effects of brand community

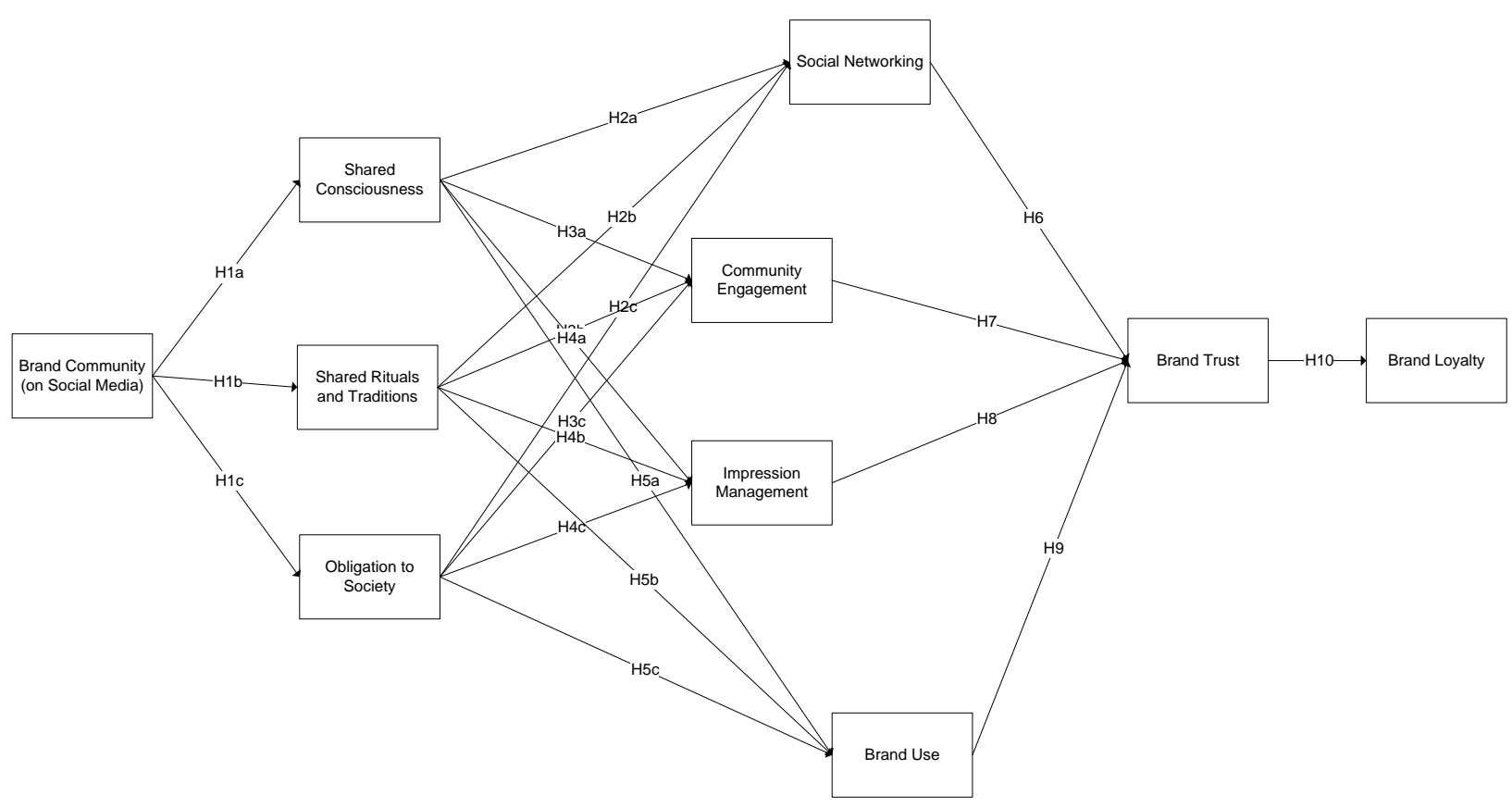


Table 1 - Means, standard deviations, reliability statistics for construct measures

\begin{tabular}{||l||c||c||c||c||}
\hline \multicolumn{1}{|c||}{ CONSTRUCTS } & $\begin{array}{c}\text { No. OF } \\
\text { ITEMS }\end{array}$ & MEAN & $\begin{array}{c}\text { STANDARD } \\
\text { DEVIATION }\end{array}$ & $\begin{array}{c}\text { CRONBACH'S } \\
\alpha\end{array}$ \\
\hline \hline Social media brand community & 6 & 10.83 & 2.76 & 0.72 \\
\hline \hline Social networking & 8 & 15.8 & 4.08 & 0.78 \\
\hline \hline Community engagement & 4 & 7.91 & 2.24 & 0.71 \\
\hline \hline Impression management & 3 & 5.91 & 1.75 & 0.71 \\
\hline Brand use practices & 3 & 5.95 & 1.72 & 0.70 \\
\hline \hline Shared consciousness & 2 & 3.96 & 1.34 & 0.72 \\
\hline Obligations to society & 2 & 3.84 & 1.55 & 0.75 \\
\hline \hline Rituals and traditions & 2 & 3.95 & 2.72 & 0.73 \\
\hline Brand loyalty & 3 & 6.73 & 1.70 & 0.86 \\
\hline \hline Brand trust & 3 & 5.34 & & 0.71 \\
\hline
\end{tabular}

Table 2 - KMO and Bartlett's test

Kaiser-Meyer-Olkin Measure of Sampling

Adequacy.

Bartlett's Test of

Approx. Chi-Square

Sphericity

df

2580.26

Sig.

630

.000 
Table 3 Factor loadings and R-square of the items in CFA

\begin{tabular}{|c|c|c|c|}
\hline Construct & Item & Factor loading & R-square \\
\hline \multirow[t]{3}{*}{ Brand community } & Ob4 & 0.491 & 0.241 \\
\hline & Ob5 & 0.657 & 0.431 \\
\hline & Ob6 & 0.724 & 0.525 \\
\hline \multirow[t]{5}{*}{ Social networking } & Sn2 & 0.643 & 0.413 \\
\hline & Sn3 & 0.688 & 0.473 \\
\hline & Sn5 & 0.629 & 0.396 \\
\hline & Sn6 & 0.572 & 0.327 \\
\hline & Sn7 & 0.613 & 0375 \\
\hline \multirow{3}{*}{$\begin{array}{l}\text { Community } \\
\text { engagement }\end{array}$} & $\mathrm{Ce} 2$ & 0.531 & 0.282 \\
\hline & $\mathrm{Ce} 3$ & 0.653 & 0.426 \\
\hline & $\mathrm{Ce} 4$ & 0.709 & 0.502 \\
\hline \multirow{2}{*}{$\begin{array}{l}\text { Shared } \\
\text { consciousness }\end{array}$} & Sc1 & 0.750 & 0.562 \\
\hline & $\mathrm{Sc} 2$ & 0.751 & 0.563 \\
\hline \multirow{3}{*}{$\begin{array}{l}\text { Impression } \\
\text { management }\end{array}$} & $\operatorname{Im} 1$ & 0.640 & 0.410 \\
\hline & $\operatorname{Im} 2$ & 0.696 & 0.485 \\
\hline & $\operatorname{Im} 3$ & 0.676 & 0.457 \\
\hline \multirow[t]{3}{*}{ Brand trust } & Bt1 & 0.631 & 0.398 \\
\hline & Bt2 & 0.569 & 0.323 \\
\hline & Bt3 & 0.560 & 0.314 \\
\hline \multirow[t]{3}{*}{ Loyalty } & L1 & 0.797 & 0.636 \\
\hline & L2 & 0.854 & \begin{tabular}{|l|l|}
0.730 \\
\end{tabular} \\
\hline & L3 & 0.803 & 0.645 \\
\hline \multirow{2}{*}{$\begin{array}{l}\text { Obligations to } \\
\text { society }\end{array}$} & Obsoc1 & 0.744 & 0.553 \\
\hline & Obsoc2 & 0.757 & 0.573 \\
\hline \multirow{2}{*}{$\begin{array}{l}\text { Rituals and } \\
\text { traditions }\end{array}$} & Tt1 & 0.806 & 0.649 \\
\hline & $\mathrm{Tt} 2$ & 0.715 & 0.511 \\
\hline \multirow[t]{3}{*}{ Brand use } & Bu1 & 0.602 & 0.363 \\
\hline & $\mathrm{Bu} 2$ & 0.637 & 0.405 \\
\hline & $\mathrm{Bu} 3$ & 0.739 & 0.545 \\
\hline
\end{tabular}

Note: See Appendix for the items. 
Table 4 - Correlation matrix

\begin{tabular}{|c|c|c|c|c|c|c|c|c|c|}
\hline & SC & OBSOC & TT & OB & SN & CE & BU & IM & LL \\
\hline SC & & & & & & & & & \\
\hline OBSOC & $.419^{* *}$ & & & & & & & & \\
\hline TT & $.388^{* *}$ & $.430^{* *}$ & & & & & & & \\
\hline OB & $.465^{* *}$ & $.481^{* *}$ & $.454^{* *}$ & & & & & & \\
\hline SN & $.538^{* *}$ & $.640^{* *}$ & $.589^{* *}$ & $.635^{* *}$ & & & & & \\
\hline CE & $.488^{* *}$ & $.584^{* *}$ & $.540^{* *}$ & $.554^{* *}$ & $.644^{* *}$ & & & & \\
\hline BU & $.424^{* *}$ & $.499^{* *}$ & $.430^{* *}$ & $.501^{* *}$ & $.564^{* *}$ & $.554^{* *}$ & & & \\
\hline IM & $.377^{* *}$ & $.484^{* *}$ & $.473^{* *}$ & $.456^{* *}$ & $.540^{* *}$ & $.540^{* *}$ & $.530^{* *}$ & & \\
\hline LL & $.339^{* *}$ & $.273^{* *}$ & $.424^{* *}$ & $.266^{* *}$ & $.317^{* *}$ & $.299^{* *}$ & $.412^{* *}$ & $.378^{* *}$ & \\
\hline BT & $.393^{* *}$ & $.471^{* *}$ & $.453^{* *}$ & $.456^{* *}$ & $.463^{* *}$ & $.468^{* *}$ & $.471^{* * *}$ & $.485^{* *}$ & $.467^{* *-1}$ \\
\hline
\end{tabular}

Notes: All coefficients are significant at $p<0.01$

$\mathrm{SC}=$ Shared consciousness, $\mathrm{OBSOC}=$ Obligation to society, TT: Rituals and traditions, $\mathrm{OB}=$ Brand community,

$\mathrm{SN}=$ Social networking, $\mathrm{CE}=$ Community engagement, $\mathrm{BU}=$ Brand use, $\mathrm{IM}=$ Impressions management, $\mathrm{LL}=$

Brand loyalty, $\mathrm{BT}=$ Brand trust. 


\section{Figure 2 - Estimated model}

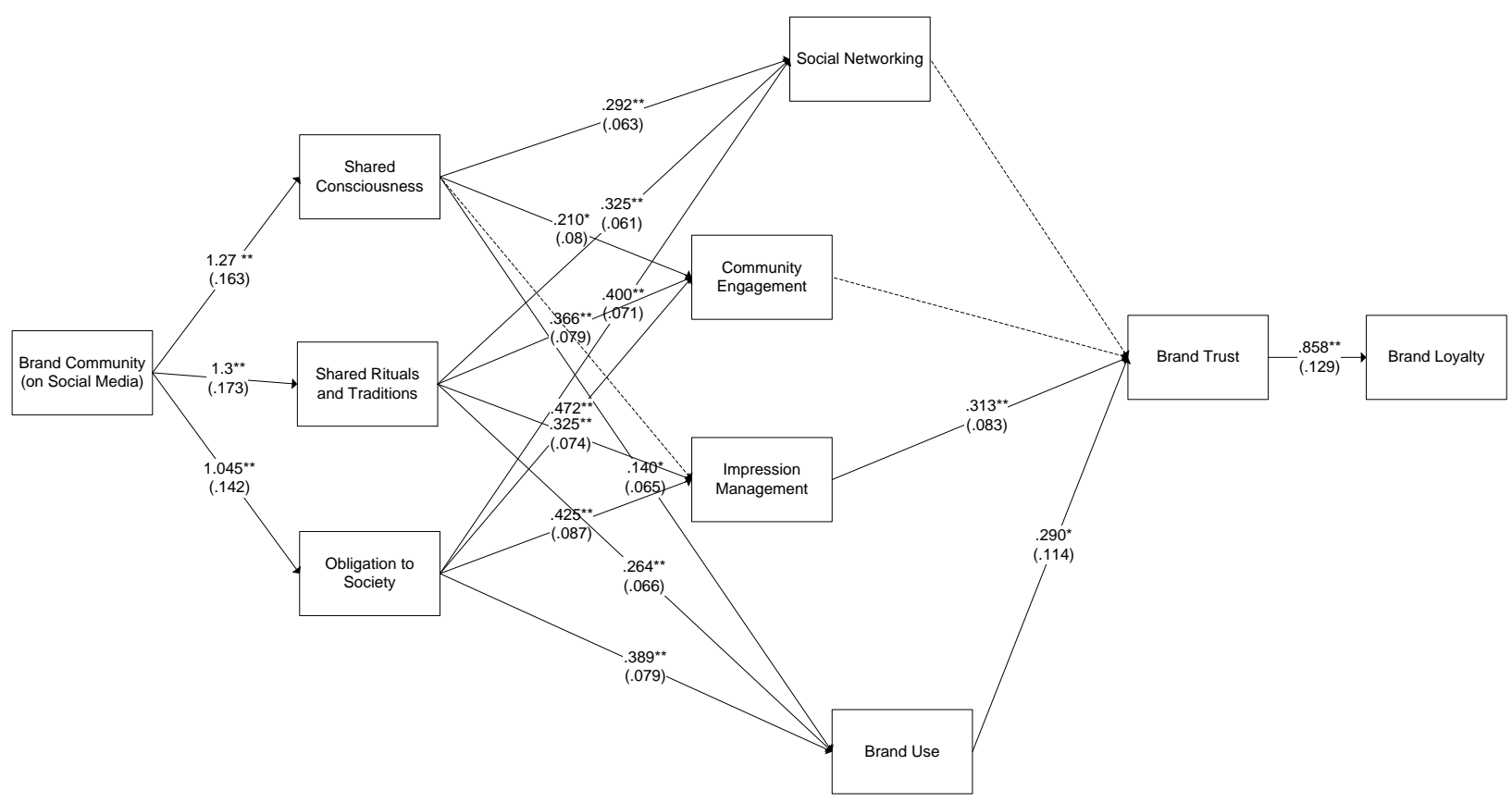

$* * p<.001, * p<.05$

Note: Unstandardized coefficients are used and standard errors are in parentheses; dashed arrows represent nonsignificant paths. 
Figure 3 The model with brand trust as partial mediator

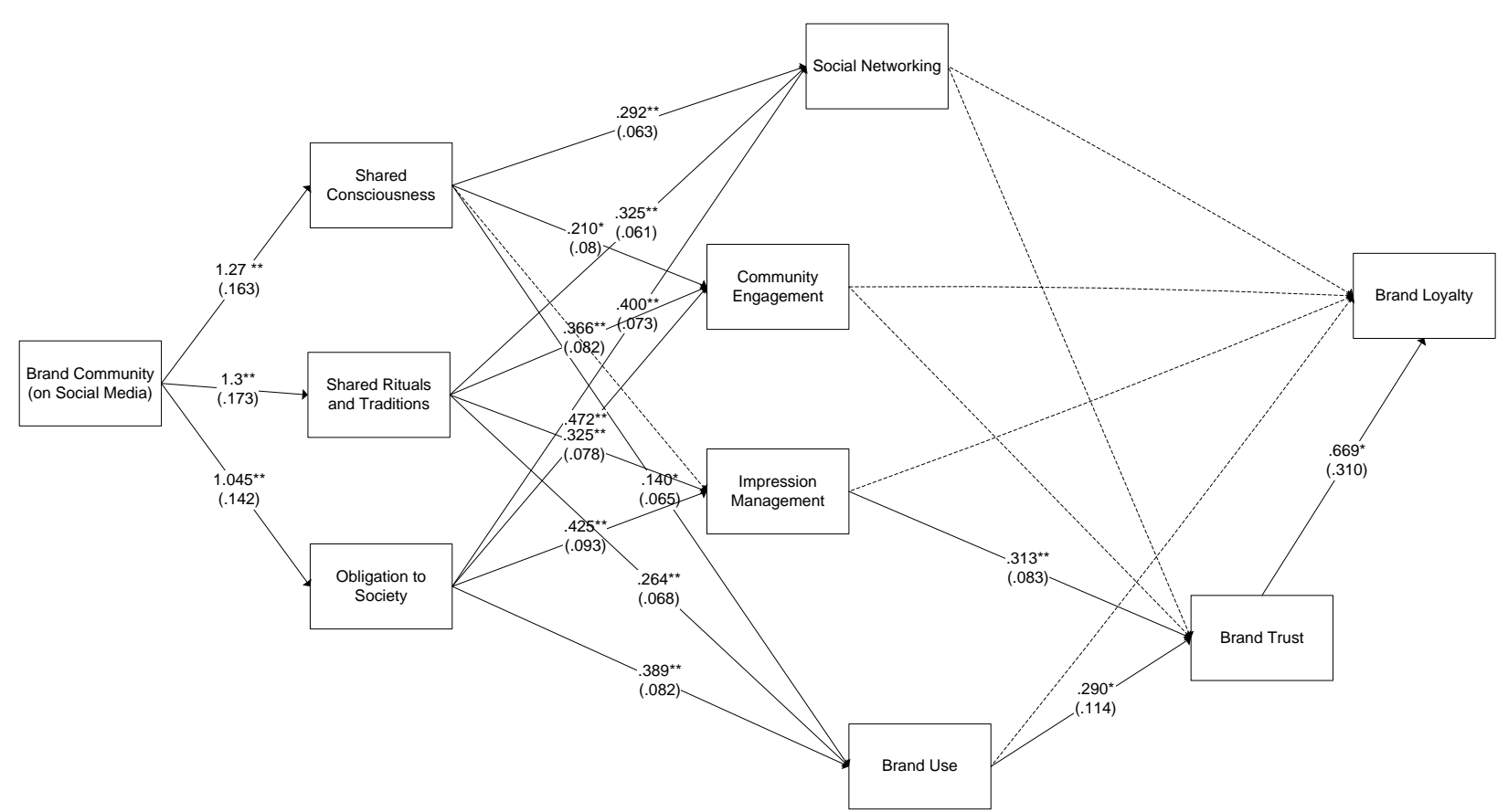

$* * p<.001, * p<.05$

Note: Unstandardized coefficients are used and standard errors are in parentheses; dashed arrows represent nonsignificant paths. 